\title{
COCONUT MEAL INCLUSION IN HIGH CONCENTRATE SHEEP DIETS AFFECTS FEED DIGESTIBILITY AND INTAKE ${ }^{1}$
}

\author{
PAULA FABRINY MAUÉS DA SILVA², SARAH OLIVEIRA SOUSA PANTOJA ${ }^{2}$, FELIPE NOGUEIRA \\ DOMINGUES ${ }^{3}$, ANIBAL COUTINHO DO REGO ${ }^{3}$, CRISTIAN FATURI*
}

\begin{abstract}
Coconut meal can be an affordable low-cost alternative to noble ingredients such as corn and soybean meal in sheep diets. The objective of this study was to evaluate the effects of coconut meal inclusions, when used as a corn and soybean meal replacement, on the intake, digestibility, and nitrogen balance of sheep diets. Twenty-four male Santa Inês lambs with body weights (BW) of $26.6 \pm 3.2 \mathrm{~kg}$ were used in the study. The animals were housed in metabolic cages and distributed in a completely randomized block design, with three treatments and eight replications. The animals received a total mixed ratio of $30 \%$ roughage (elephant grass) and $70 \%$ concentrate. The animals were fed on two experimental diets with $11 \%$ and $22 \%$ coconut meal inclusion and a control diet (without coconut meal). Dry matter (DM), crude protein (CP), neutral detergent fiber (NDF), acid detergent fiber (ADF), and non-fibrous carbohydrate (NFC) intake as a percentage of BW were negatively influenced by the inclusion of coconut meal. The ether extract (EE) intake increased but did not differ between the $11 \%$ and $22 \%$ coconut meal diets. Furthermore, the digestibility of DM, CP, EE, and ADF did not differ between the two evaluated diets. The inclusion of coconut meal reduced NDF digestibility and increased that of NFC. The level of inclusion of coconut meal in the diet must be based on the EE content in the meal; keeping the EE intake below $0.16 \%$ of the BW helped to avoid limited intake of feed.
\end{abstract}

Keywords: Agricultural byproduct. Ether extract. Lambs. Metabolic trial.

\section{TORTA DE COCO EM DIETAS PARA OVINOS COM ALTO CONCENTRADO AFETA DIGESTIBILIDADE E CONSUMO}

\begin{abstract}
RESUMO - A torta de coco pode ser uma alternativa disponível e de baixo custo para substituir ingredientes nobres como o milho e o farelo de soja em dietas para ovinos. Objetivou-se com esse estudo, avaliar a inclusão de torta de coco em substituição ao milho e o farelo de soja em dietas para ovinos sobre o consumo, a digestibilidade aparente dos nutrientes e balanço de nitrogênio. Foram utilizados 24 cordeiros machos da raça Santa Inês, com peso corporal (PC) de 26,6 $\pm 3,2 \mathrm{~kg}$, mantidos em gaiolas metabólicas, distribuídos em delineamento em blocos casualizados, com três tratamentos e oito repetições. Os animais receberam ração total com $30 \%$ de volumoso (capim elefante) e $70 \%$ de concentrado. Foram testadas uma dieta controle (sem torta) e outras duas, com 11 e $22 \%$ de inclusão da torta de coco. Os consumos de matéria seca (MS), proteína bruta (PB), fibra em detergente neutro (FDN), fibra em detergente ácido (FDA) e carboidratos não fibrosos (CNF) em $\%$ do $\mathrm{PC}$ foram influenciados negativamente pela adição da torta de coco. O consumo de extrato etéreo (EE) aumentou, sem diferença entre dietas com 11 e $22 \%$. A digestibilidade da MS, PB, EE e FDA não diferiram entre as dietas avaliadas. A inclusão da torta reduziu a digestibilidade da FDN e aumentou a dos CNF. O nível de inclusão da torta de coco na dieta deve estar relacionado ao teor de extrato etéreo da torta, mantendo o consumo de EE abaixo de $0,16 \%$ do peso corporal para não limitar a ingestão.
\end{abstract}

Palavras-chave: Coproduto. Extrato Etéreo.Cordeiros. Ensaio metabólico.

\footnotetext{
${ }^{*}$ Corresponding author

${ }^{1}$ Received for publication in $05 / 21 / 2020$; accepted in 02/22/2021.

Paper extracted from master's dissertation the of the first author

${ }^{2}$ Institute of Health and Animal Production, Universidade Federal Rural da Amazônia, Belém, PA, Brazil; fabrinymaues@gmail.com ORCID: 0000-0003-0855-3163, sarah_oliver90@hotmail.com - ORCID: 0000-0002-3431-1769, felipend@gmail.com - ORCID: 00000002-6809-5320, anibalcr@gmail.com - ORCID: 0000-0002-5452-0832, cristian.faturi@ufra.edu.br - ORCID: 0000-0002-6676-1844.
} 


\section{INTRODUCTION}

Sheep meat has the fourth highest consumption rate worldwide after pork, poultry, and beef (FURNOLS; GUERRERO, 2014). Despite the expansion of sheep farming in Brazil in previous years, sheep producers still face many technical difficulties in the production of competitive and affordable lamb meat (RANIERI; NUNES; GAMEIRO, 2015). For this reason, sheep production is still considered a secondary or subsistence activity in many regions of the country, but most predominantly in the north and northeast (HERMUCHE et al., 2013).

The pressure to increase the volume and efficiency of lamb/sheep meat production in the coming years will be much greater for the survival of the chain. Given this scenario, finishing lambs that are raised in feedlots can prove to be promising specimens of the production potential of these animals (LIMA et al., 2017). However, the duration of the animal's stay in the feedlot and the choice of concentrates used in the diet are fundamental to the cost of production (SANTOS et al., 2014).

Corn and soybean are the predominant components of ruminant diets (PINTO; MILLEN, 2018). However, as they are also used worldwide in the production of biofuels, and in human and nonruminant diets, the added value of these products has increased (MEADE et al., 2016). This has consequently encouraged the search for low-cost alternative ingredients for use in sheep production.

Compared to these noble ingredients, byproducts from the agroindustry provide low-cost feed options, with variable availability depending upon the region in which they are produced (ROGÉRIO et al., 2016). In the last decade, Brazil has emerged as the world's fourth largest producer of coconut (Cocos nucifera; HOE, 2018). North and northeast Brazil have the largest coconut plantations in the country (BRAINER, 2018), and are areas of economic importance that generate a multitude of products. However, environmental concerns have emerged regarding the disposal of residues from coconut processing, such as the meal that is generated after the production of coconut milk and oil (MARTINS et al., 2016). Coconut meal has a high concentration of protein and lipids, a characteristic that provides it with ample versatility to replace corn and soybean meal in animal diets (BOSA et al., 2012).

Previous research carried out to evaluate the use of coconut meal in sheep diets showed that with roughage-concentrate ratios of 40:60, the inclusion of $50 \%$ coconut meal in the concentrate $30 \%$ of the dry matter (DM) in diet limits feed consumption by animals (BOSA et al., 2012; IRINO et al., 2011). However, with $25 \%$ (15\% of the DM in the diet) inclusion, the results of digestibility were similar to those of diets without coconut meal. Thus, it is essential that we understand the limits of this meal when fed to sheep, especially in diets with a high proportion of concentrate, such as those with 30:70 roughage-concentrate ratios. The objective of this study was to evaluate the effects of replacing corn and soybean meal in sheep diets with coconut meal on feed intake, apparent digestibility of nutrients, and the nitrogen balance of the animal.

\section{MATERIAL AND METHODS}

The experiment was conducted at the Metabolic Studies Unit for Small Ruminants of the Institute of Health and Animal Production of the Federal Rural University of the Amazon, Campus Belém, Pará. We used 24, approximately 6-monthold, male, non-castrated sheep, with an average body weight of $26.6 \pm 3.2 \mathrm{~kg}$ for the experiments. The animals were kept in metabolic cages and provided with feeders, saltshakers, water drinkers, and devices for the total collection of feces and urine. The animals were maintained for $21 \mathrm{~d}$ for the experiment, including $14 \mathrm{~d}$ for adaptation to the experimental diets and the environment, and another $7 \mathrm{~d}$ for sample collection. Before the adaptation period, the animals were examined for zootechnical and sanitary abnormalities, endo control, and ectoparasites; as a prophylactic measure, the animals were dewormed and subsequently injected with vitamins $\mathrm{A}, \mathrm{D}$, and $\mathrm{E}$.

The chemical composition of the ingredients used in the diets were analyzed (Table 1), according to the methodology described later.

Three experimental diets were formulated (Table 2) composed of a roughage portion (30\%) and a concentrated portion $(70 \%)$. These consisted of a control diet (without coconut meal) and two others, with $11 \%$ and $22 \%$ coconut meal inclusions, replacing the ground corn and soybean meal, based on the concentrate DM.

It was used as roughage the elephant grass cv. Napier (Pennisetum purpureum) supplied fresh. The grass was harvested manually when it was $1.50 \mathrm{~m}$ in height, $20 \mathrm{~cm}$ from the soil, after approximately 45 days of regrowth. The grass was then chopped in a conventional forage chopper, and adjusted to obtain a theoretical particle size of $1.5 \mathrm{~cm}$. The concentrate portion of the diet was composed of grains of ground corn, soybean meal, coconut meal mechanically extracted by pressing, and wheat bran, which were distributed in varying proportions according to the different treatments (Table 2). The diets were formulated to have the same crude protein (CP) content and meet the requirements for the daily weight gain of $200 \mathrm{~g} / \mathrm{animal} / \mathrm{day}$, according to the recommendations described in the National Research Council for Small Ruminants (NRC, 2007). The diets were provided twice a day, $50 \%$ at $0800 \mathrm{~h}$ and $50 \%$ at $1700 \mathrm{~h}$ in the form of a complete ration at will. The leftovers were quantified daily for 
adjustment and determination of voluntary consumption, to provide approximately $10 \%$ of leftovers based on the DM of the feed. Mineral salt was available ad libitum to animals.

Table 1. Chemical composition of ingredients used in the experimental diets.

\begin{tabular}{cccccc}
\hline Item (\%) & Elephant grass & Coconut meal & Ground corn & Soybean meal & Wheat bran \\
\hline $\mathrm{DM}^{1}$ & 17.97 & 89.50 & 86.48 & 87.11 & 85.99 \\
$\mathrm{OM}^{2}$ & 93.70 & 95.89 & 98.48 & 93.19 & 94.20 \\
$\mathrm{MM}^{3}$ & 6.30 & 4.11 & 1.52 & 6.81 & 5.80 \\
$\mathrm{CP}^{4}$ & 6.43 & 20.35 & 9.23 & 44.34 & 23.70 \\
$\mathrm{EE}^{5}$ & 1.30 & 26.43 & 3.04 & 3.34 & 2.72 \\
$\mathrm{NDF}_{\text {ap }}^{6}$ & 70.39 & 41.22 & 23.66 & 26.13 & 45.45 \\
$\mathrm{ADF}^{7}$ & 41.86 & 27.68 & 3.34 & 9.75 & 13.72 \\
$\mathrm{NFC}^{8}$ & 15.58 & 7.89 & 55.83 & 21.41 & 11.32 \\
$\mathrm{LIG}^{9}$ & 7.48 & 2.49 & 0.22 & 1.40 & 2.54 \\
\hline
\end{tabular}

Dry matter ${ }^{1}$, organic matter ${ }^{2}$; mineral matter ${ }^{3}$, crude protein $^{4}$, ethereal extract ${ }^{5}$, neutral detergent fiber corrected for ash and protein ${ }^{6}$, acid detergent fiber ${ }^{7}$, non-fibrous carbohydrate ${ }^{8}$ and lignin $^{9}$.

Table 2. Composition of the experimental diets after inclusion of the coconut meal.

\begin{tabular}{|c|c|c|c|}
\hline \multirow{2}{*}{ Item } & \multicolumn{3}{|c|}{ Concentration of coconut meal in the diet } \\
\hline & $0 \%$ & $11 \%$ & $22 \%$ \\
\hline & \multicolumn{3}{|c|}{ Proportion of ingredients (\% of DM) } \\
\hline Coconut meal & - & 11.00 & 22.00 \\
\hline Soybean meal & 20.00 & 15.00 & 10.00 \\
\hline Ground corn & 31.00 & 25.00 & 19.00 \\
\hline Wheat bran & 18.00 & 18.00 & 18.00 \\
\hline Urea & 0.50 & 0.50 & 0.50 \\
\hline Calcitic limestone & 0.50 & 0.50 & 0.50 \\
\hline \multirow[t]{2}{*}{ Elephant Grass } & 30.00 & 30.00 & 30.00 \\
\hline & \multicolumn{3}{|c|}{ Chemical composition $(\%)$} \\
\hline $\mathrm{DM}^{1}$ & 65.10 & 65.40 & 68.22 \\
\hline $\mathrm{OM}^{2}$ & 94.19 & 94.17 & 94.15 \\
\hline $\mathrm{MM}^{3}$ & 5.81 & 5.83 & 5.85 \\
\hline $\mathrm{CP}^{4}$ & 19.32 & 18.79 & 18.26 \\
\hline $\mathrm{EE}^{5}$ & 2.49 & 5.05 & 7.61 \\
\hline $\mathrm{NDF}_{\mathrm{ap}}{ }^{6}$ & 45.51 & 47.01 & 48.52 \\
\hline $\mathrm{ADF}^{7}$ & 18.02 & 20.37 & 22.73 \\
\hline $\mathrm{LIG}^{8}$ & 2.24 & 3.68 & 4.31 \\
\hline $\mathrm{NFC}^{9}$ & 28.27 & 24.72 & 21.16 \\
\hline
\end{tabular}

Dry matter ${ }^{1}$, organic matter ${ }^{2}$; mineral matter ${ }^{3}$, crude protein $^{4}$, ethereal extract ${ }^{5}$, neutral detergent fiber corrected for ash protein ${ }^{6}$, acid detergent fiber ${ }^{7}$, lignin $^{8}$ and non-fibrous carbohydrate ${ }^{9}$.

Rev. Caatinga, Mossoró, v. 34, n. 3, p. 692 - 701, jul. - set., 2021 
During the collection period, after the elephant grass was cut, chopped, and homogenized, a $200 \mathrm{~g}$ sample was taken daily, which was packaged and identified, to compose the sample composed of the $7 \mathrm{~d}$ of collection. The leftovers of the diets were weighed daily on a precision scale, homogenized and then sampled. During feces collection, the fecal material stored in the collection box was weighed on a precision scale daily, and a sample of $10 \%$ of the total registered weight was taken. All samples of ingredients, leftovers, and feces were packed in plastic bags with total sealing, identified, and then kept in a freezer at $-20{ }^{\circ} \mathrm{C}$. At the end of the experimental test, the leftovers and feces were thawed and homogenized to generate a pool of samples for each animal unit for the $7 \mathrm{~d}$ of collection.

For urine collection, the volume produced per animal was measured daily, then $10 \%$ of the total volume was collected, and the material was identified and stored in a glass container with the total seal, and kept in a freezer at $-20{ }^{\circ} \mathrm{C}$. In the urine collection buckets, $10 \mathrm{~mL}$ of 1:1 hydrochloric acid was added daily to avoid losses due to the volatilization of the nitrogen compounds.

To determine the chemical composition, the samples of the ingredients, leftovers, and feces were thawed, weighed, and subjected to pre-drying in a forced air circulation oven $\left(55^{\circ} \mathrm{C}\right.$ for $72 \mathrm{~h}$ ), and subsequently ground in a Willey knife mill with a 1-mm-diameter sieve. The DM (Official Method 934.01), mineral matter (MM; Official Method 923.03), and CP (Official Method 978.04) contents were determined according to official methods of the Association of Official Analytical Chemists (AOAC, 1990). The EE content was determined using a Fat Extractor device model XT10-Ankom ${ }^{\circledR}$. The levels of neutral detergent fiber (NDF), acid detergent fiber (ADF), and lignin (LIG) were determined using method 973.18 (AOAC, 1990). The CNF content was calculated according to the method of Detmann and Valadares Filho (2010).

The levels of DM and total nitrogen were determined in the urine samples. The apparent nitrogen balance $(\mathrm{BN})$ was calculated according to equations (1), (2), and (3), and expressed in g/ animal:

$$
\begin{aligned}
& \text { Ningested }=\text { Noffered }- \text { Nleftovers } \\
& \text { Nretained }=\text { Ningested }-(\text { Nfecal }+ \text { Nurinary }) \\
& \text { Nabsorbed }=\text { Ningested }-N \text { fecal }
\end{aligned}
$$

The voluntary intake of nutrients, based on DM, was determined using the difference between the total diet provided and the leftovers, obtaining the consumptions of DM, OM, CP, EE, NDF, and
ADF

Consumption of the DM, OM, CP, EE, NDF, and ADF based on the metabolic weight (BW 0.75), were calculated according to equation (4):

$$
B W^{0.75}=\frac{B W^{0.75}}{\text { Nutri I in grams }}
$$

The consumption of DM, MM, CP, EE, NDF, and $\mathrm{ADF}$ based on body weight $(\% \mathrm{BW})$ were calculated according to equation (5):

$$
\% B W=\frac{B W}{\text { Nutri I in grams }}
$$

The apparent digestibility coefficients (ADCs) were calculated according to equation (6):

$$
A D C(\%)=\frac{N \text { ingested }(g)-N \text { excreted }(g)}{N \text { ingested }(g)} \times 100
$$

The stratification of particles from the leftover feed supplied to the animals was also evaluated according to the methodology proposed by Lammers, Buckmaster and Heinrinchs (1996).

A randomized block design was used, with three treatments (diets), two blocks (initial weight), and eight repetitions (animals). The data generated were subjected to analysis of variance, and the means were compared using the Tukey test at a 5\% probability level using the statistical program Statistical Analysis System (SAS, 2008).

\section{RESULTS AND DISCUSSION}

Table 3 shows the average daily intake of $\mathrm{DM}, \mathrm{OM}, \mathrm{CP}, \mathrm{EE}, \mathrm{NDF}, \mathrm{ADF}$, and NFC in $\mathrm{kg} /$ animal/day, body weight (percentage $\mathrm{BW}$ ), and inunit of metabolic size (UMS).

Note that the inclusion of coconut meal significantly reduced $(P<0.0001)$ the consumption of DM, OM, CP, NDF, and NFC when considering the percentage $\mathrm{BW}$ and UMS. When observing the consumption of each animal in $\mathrm{kg} / \mathrm{animal} / \mathrm{day}$, the consumption of DM and OM was similar between the control diets and the $11 \%$ inclusion of coconut meal; however, it was significantly higher $(P<0.0001)$ than that in the $22 \%$ diet. When observing the consumption in g/animal/day, the BP was significantly different $(P<0.0001)$ between the three diets and the NDF was the same in the coconut meal treatments, which were significantly different $(P<0.0001)$ from the control group. However, the best way to express this data is via the animals' BW, as it corrects for this variation. 
There was a difference in EE consumption when comparing the diets that contained coconut meal and those that did not. The intake of EE in $\mathrm{g}$ /animal/day, in percentage BW, and in UMS was lower in the control treatment, whereas there was no difference between the two coconut meal treatments
$(11 \%$ and $22 \%)$. This effect was expected, considering the higher concentrations of lipids in the coconut meal when compared to corn, soybeans, and wheat $(26.43 \%, 3.04 \%, 3.34 \%$, and $2.72 \%$, respectively).

Table 3. Intake of dry matter (DM) and nutrients with or without the inclusion of coconut meal in sheep diets.

\begin{tabular}{|c|c|c|c|c|c|c|}
\hline \multirow{3}{*}{ Voluntary intake } & \multicolumn{3}{|c|}{ Concentration of coconut meal } & \multirow{3}{*}{$\mathrm{VC}(\%)^{88}$} & \multirow{3}{*}{$\mathrm{SE}^{9}$} & \multirow{3}{*}{$P$-Value } \\
\hline & $0 \%$ & $11 \%$ & $22 \%$ & & & \\
\hline & \multicolumn{3}{|c|}{$\mathrm{Kg}$ /animal/day } & & & \\
\hline $\mathrm{DM}^{1}$ & $0.879^{\mathrm{a}}$ & $0.780^{\mathrm{a}}$ & $0.535^{\mathrm{b}}$ & 15.10 & 0.0352 & $<0.0001$ \\
\hline $\mathrm{OM}^{2}$ & $0.829^{\mathrm{a}}$ & $0.758^{\mathrm{a}}$ & $0.542^{\mathrm{b}}$ & 10.64 & 0.0232 & $<0.0001$ \\
\hline $\mathrm{CP}^{3}$ & $0.178^{\mathrm{a}}$ & $0.158^{\mathrm{b}}$ & $0.107^{\mathrm{c}}$ & 11.50 & 0.0052 & $<0.0001$ \\
\hline $\mathrm{EE}^{4}$ & $0.023^{\mathrm{b}}$ & $0.046^{\mathrm{a}}$ & $0.040^{\mathrm{a}}$ & 18.54 & 0.0026 & $<0.0001$ \\
\hline $\mathrm{NDF}^{5}$ & $0.380^{\mathrm{a}}$ & $0.344^{\mathrm{a}}$ & $0.255^{\mathrm{b}}$ & 14.50 & 0.0152 & 0.0001 \\
\hline $\mathrm{ADF}^{6}$ & 0.142 & 0.141 & 0.120 & 14.46 & 0.0066 & 0.0565 \\
\hline \multirow[t]{2}{*}{$\mathrm{NFC}^{7}$} & $0.247^{\mathrm{a}}$ & $0.212^{\mathrm{b}}$ & $0.140^{\mathrm{c}}$ & 9.26 & 0.0062 & $<0.0001$ \\
\hline & \multicolumn{3}{|c|}{ Percentage body weight } & & & \\
\hline $\mathrm{DM}^{1}$ & $3.37^{\mathrm{a}}$ & $2.90^{\mathrm{b}}$ & $2.01^{\mathrm{c}}$ & 8.60 & 0.1116 & $<0.0001$ \\
\hline $\mathrm{OM}^{2}$ & $3.19^{\mathrm{a}}$ & $2.82^{\mathrm{b}}$ & $2.05^{\mathrm{c}}$ & 7.93 & 0.0629 & $<0.0001$ \\
\hline $\mathrm{CP}^{3}$ & $0.68^{\mathrm{a}}$ & $0.59^{\mathrm{b}}$ & $0.40^{\mathrm{c}}$ & 8.75 & 0.0145 & $<0.0001$ \\
\hline $\mathrm{EE}^{4}$ & $0.09^{\mathrm{b}}$ & $0.16^{\mathrm{a}}$ & $0.16^{\mathrm{a}}$ & 15.98 & 0.0071 & $<0.0001$ \\
\hline $\mathrm{NDF}^{5}$ & $1.46^{\mathrm{a}}$ & $1.28^{\mathrm{b}}$ & $0.96^{\mathrm{c}}$ & 8.25 & 0.0465 & $<0.0001$ \\
\hline $\mathrm{ADF}^{6}$ & $0.55^{\mathrm{a}}$ & $0.52^{\mathrm{a}}$ & $0.45^{\mathrm{b}}$ & 10.61 & 0.0207 & 0.0062 \\
\hline \multirow[t]{2}{*}{$\mathrm{NFC}^{7}$} & $0.95^{\mathrm{a}}$ & $0.79^{\mathrm{b}}$ & $0.53^{\mathrm{c}}$ & 9.54 & 0.0212 & $<0.0001$ \\
\hline & \multicolumn{3}{|c|}{ UMS (g kg BW $\left.{ }^{0.75-1}\right)$} & & & \\
\hline $\mathrm{DM}^{1}$ & $76.12^{\mathrm{a}}$ & $65.83^{b}$ & $45.66^{\mathrm{c}}$ & 10.14 & 2.5615 & $<.0001$ \\
\hline $\mathrm{OM}^{2}$ & $71.91^{\mathrm{a}}$ & $63.96^{\mathrm{b}}$ & $46.45^{\mathrm{c}}$ & 2.80 & 1.4327 & $<.0001$ \\
\hline $\mathrm{CP}^{3}$ & $15.49^{\mathrm{a}}$ & $13.30^{\mathrm{b}}$ & $9.16^{\mathrm{c}}$ & 3.34 & 0.3342 & $<.0001$ \\
\hline $\mathrm{EE}^{4}$ & $2.03^{b}$ & $3.73^{\mathrm{a}}$ & $3.53^{\mathrm{a}}$ & 15.57 & 0.1638 & $<.0001$ \\
\hline $\mathrm{NDF}^{5}$ & $32.94^{\mathrm{a}}$ & $29.02^{\mathrm{b}}$ & $21.77^{\mathrm{c}}$ & 9.68 & 1.0746 & $<.0001$ \\
\hline $\mathrm{ADF}^{6}$ & $12.33^{\mathrm{a}}$ & $11.91^{\mathrm{a}}$ & $10.25^{\mathrm{b}}$ & 11.20 & 0.4751 & 0.0102 \\
\hline $\mathrm{NFC}^{7}$ & $21.46^{\mathrm{a}}$ & $17.91^{\mathrm{b}}$ & $11.99^{\mathrm{c}}$ & 6.32 & 0.4604 & $<.0001$ \\
\hline
\end{tabular}

Dry matter ${ }^{1}$, organic matter ${ }^{2}$, crude protein ${ }^{3}$, ethereal extract ${ }^{4}$, neutral detergent fiber ${ }^{5}$, acid detergent fiber ${ }^{6}$, non-fibrous carbohydrates $^{7}$, variation coefficient ${ }^{8}$ and standard error of the average ${ }^{9}$.

*Means followed by different letters in the same row differ statistically from each other using Tukey's test.

The ADF intake in kg/animal/day was similar between all diets, whereas the consumption of $\mathrm{ADF}$ in percentage $\mathrm{BW}$ was the same between the control and $11 \%$ coconut meal diet, as well as between the
$22 \%$ and $11 \%$ coconut meal diets, when compared to each other. When observing the consumption of DM as a percentage of $\mathrm{CP}$, it appears that the control group reached a value close to the $3.44 \%$ 
recommended by the National Research Council (NRC, 2007) for this animal category. However, the values obtained in the other two treatments $(11 \%$ and $22 \%$ ) were below this.

In general, it was observed that animals fed with concentrate containing coconut meal rejected the concentrated fraction of the diet (Table 4) to a greater or lesser degree. This was confirmed by the evaluation of the ingestion behavior of animals using the method of stratification of particles from the leftovers of the feed supplied. It was found that the leftovers of the group that received a diet containing $22 \%$ coconut meal presented a greater proportion of particles retained in the third sieve and bottom $(P<$ 0.01 ), with $33 \%$ and $43 \%$ retention, respectively. This animal group selected roughage feed for ingestion, thus leaving a large part of the concentrated fraction.
The stratification of particles from the leftovers generated by the control group (without coconut meal) showed greater retention in the first sieve $(59 \%)(P<0.01)$, which mainly retained roughage particles, followed by the $11 \%$ coconut meal group ( $42 \%$ retention) and the $22 \%$ coconut meal group ( $11 \%$ retention). This shows that when the concentration of coconut meal was increased, the amount of concentrate in the leftovers also increased, thus demonstrating the possible rejection or selectivity on the part of the animals. Oliveira et al. (2017) explained that it is common to observe, in the case of ruminants, a reduction in DM intake when there is an increase in lipid levels in the diet, and the rejection of a feed or diet must be related to palatability, physical form, or possible metabolic disorders.

Table 4. Stratification of particles from leftover diets offered to sheep with different inclusions of coconut meal.

\begin{tabular}{ccccccc}
\hline \multirow{2}{*}{ Sieve size } & \multicolumn{3}{c}{ Concentration of coconut meal } & \multirow{2}{*}{ VC $^{1} \%$} & SE $^{2}$ & P value \\
\cline { 2 - 4 } & $0 \%$ & $11 \%$ & $22 \%$ & & & \\
\cline { 2 - 4 } $19 \mathrm{~mm}$ & $59^{\mathrm{a}}$ & $42^{\mathrm{a}}$ & $11^{\mathrm{b}}$ & 53.06 & 7.00 & 0.0003 \\
$7.8 \mathrm{~mm}$ & $17^{\mathrm{ab}}$ & $28^{\mathrm{a}}$ & $13^{\mathrm{b}}$ & 47.93 & 3.30 & 0.0105 \\
$1.8 \mathrm{~mm}$ & $12^{\mathrm{b}}$ & $16^{\mathrm{b}}$ & $33^{\mathrm{a}}$ & 47.06 & 3.36 & 0.0004 \\
Ground & $12^{\mathrm{b}}$ & $14^{\mathrm{b}}$ & $43^{\mathrm{a}}$ & 40.74 & 3.31 & 0.0001 \\
\hline
\end{tabular}

Coefficient of variation ${ }^{1}$ and standard error of the mean ${ }^{2}$.

* Means followed by different letters in the same row differ statistically from each other using Tukey's test.

Limitations in the intake of the DM and other nutrients probably did not occur because of the lipid level of the diet, as the concentration of the EE in the treatment with $11 \%(5.05 \%)$ was within the range of the dietary EE ( 5 at $7 \%$ ). This range is known to be acceptable for sheep and will not result in a reduced intake, either by regulatory mechanisms that control feed intake or by the limited ability of ruminants to oxidize fatty acids (PALMQUIST; MATTOS, 2011). A possible cause for the compromised intake of the diet containing $11 \%$ coconut meal is the profile of the fatty acids present in these lipids.

Correia et al. (2014) did not observe the influence of diets with different lipid levels on consumption in sheep fed with canola grains, canola meal, and canola bran, presenting $8.40 \%, 5.85 \%$, and $4.25 \% \mathrm{EE}$ in the diets, respectively. Fiorentini et al. (2013) stated that the mechanisms by which the lipid levels in the diet affect the intake of DM, although not clear, may encompass the effect of fat on ruminal fermentation, intestinal motility, diet acceptability, fat oxidation in the liver, length chain, and degree of unsaturation.

The effect of EE on voluntary consumption depends not only on the lipid level of the diet, but also on its physical form and type. According to Correia et al. (2014), coconut meal contains more than $80 \%$ saturated fatty acids, with lauric acid (12 C) and myristic acid (14 C) corresponding to $40.8 \%$ and $20.3 \%$ of the total, respectively. Palmquist and Mattos (2011) explained that the toxicity of fatty acids to ruminal microorganisms is related to their amphiphilic nature, i.e., those that are soluble in both organic solvents and water. Such acids include medium-chain saturated fatty acids (10-14 carbon atoms) and long-chain polyunsaturated fatty acids. Therefore, the toxicity seems to be related to acids that have greater solubility in water and cell membranes, making them potential causes of reduced feed intake.

When analyzing the lipid supply sources, it appears that the highest proportion of dietary EE in treatments with $11 \%$ and $22 \%$ inclusion was from coconut meal. Thus, it is believed that, possibly, the level of incorporation of the coconut meal associated with the high proportion of concentrate, may have influenced the acceptability of the diets by the animals, such that the animals reached their limit in 
the consumption of EE with this fatty acid profile. Based on the observation that at the lowest level of inclusion of coconut meal (11\%), the DM consumption of the animals was already affected with $5.05 \%$ total EE, it can be concluded that the limit of the EE consumption was probably reached at around $0.16 \%$ of the BW or $44 \mathrm{~g} /$ animal/day. Souza Júnior et al. (2011), evaluated the inclusion of increasing levels of coconut meal $(0.4 ; 0.8$ and $1.2 \%$ of $\mathrm{BW})$ replacing roughage, and did not observe any effect on the consumption of DM; however, they obtained the consumption from only $21.79 \mathrm{~g} / \mathrm{animal} /$ day of EE for the highest level of inclusion of coconut meal.

Similar results to those of the present study were obtained by Bringel et al. (2011) with palm oilbased diets, which also justified the limitation of DM consumption with the type of fatty acids present in the meal, as palm kernel oil is composed of $47.5 \%$ lauric acid (12 C) and 16.4\% myristic acid (14 C). Thus, the profile of fatty acids presents in the coconut meal and the proportion in which they were added to the total diet seems to justify the reduction in the consumption of DM and, consequently, the intake of other nutrients in the diets containing coconut meal.

Bosa et al. (2012) used 12 male sheep that were on average 5 months of age and had approximate $\mathrm{BW}$ of $19.5 \mathrm{~kg}$, to evaluate the MS consumption in diets with $25 \%, 50 \%$, and $75 \%$ inclusion of coconut meal in the concentrate, with a roughage-concentrate ratio of 40:60. They found that consumption was affected only after treatment with $50 \%$ inclusion of coconut meal, when the animals also reached EE consumptions of $0.18 \%$ of $\mathrm{BW}$, which remained constant with the increasing inclusion of coconut meal in the diet.

Unlike the results obtained by Bosa et al. (2012), in the present study, a reduction in consumption was observed in the diet containing $11 \%$ coconut meal inclusion. The probable justification for this difference is in the roughageconcentrate ratio used in this study (30:70) and in the highest EE concentration of the meal used, thus demonstrating that the animals reached their limit in EE consumption $(0.16 \%$ of $\mathrm{PV})$ with the smallest inclusion of coconut meal.

The EE content in the coconut meal used in this study was higher than the values reported by Bosa et al. (2012), Irino et al. (2011), and Souza Júnior et al. (2011) at 19.05\%, 14.44\%, and 8.80\%, respectively. The presumed justification for such variation is the efficiency of the extraction of oil or coconut milk and the method of extraction (mechanical or chemical) used within the processing industry. This indicates that the extraction process can influence the nutritional value of a meal, generating different chemical compositions.

Unlike the consumption parameters, there was no effect of the inclusion of coconut meal on the apparent digestibility coefficients of DM, OM, CP, $\mathrm{EE}$, and ADF (Table 5). According to Van Soest (1994), the apparent digestibility values of the DM could be considered high, with values above $60 \%$.

Table 5. Coefficients of the apparent digestibility of nutrients as a function of the levels of inclusion of the coconut meal.

\begin{tabular}{|c|c|c|c|c|c|c|}
\hline \multirow{2}{*}{ Digestibility } & \multicolumn{3}{|c|}{ Concentration of coconut meal } & \multirow{2}{*}{$\mathrm{VC} \%{ }^{8}$} & \multirow{2}{*}{$\mathrm{SE}^{9}$} & \multirow{2}{*}{$\mathrm{P}$ value } \\
\hline & $0 \%$ & $11 \%$ & $22 \%$ & & & \\
\hline $\mathrm{DM}^{1}$ & 71.88 & 68.15 & 66.48 & 8.46 & 2.0804 & 0.1907 \\
\hline $\mathrm{OM}^{2}$ & 74.13 & 72.25 & 74.47 & 6.15 & 1.6187 & 0.5811 \\
\hline $\mathrm{CP}^{3}$ & 79.36 & 78.25 & 70.51 & 21.25 & 5.7967 & 0.5020 \\
\hline $\mathrm{EE}^{4}$ & 85.67 & 80.87 & 95.72 & 17.20 & 5.4649 & 0.1573 \\
\hline $\mathrm{NDF}^{5}$ & $65.85^{\mathrm{a}}$ & $56.16^{\mathrm{b}}$ & $55.87^{\mathrm{b}}$ & 10.39 & 2.1906 & 0.0055 \\
\hline $\mathrm{ADF}^{6}$ & 52.84 & 45.72 & 51.34 & 16.21 & 2.8914 & 0.2043 \\
\hline $\mathrm{NFC}^{7}$ & $81.58^{\mathrm{b}}$ & $89.91^{\mathrm{ab}}$ & $96.92^{\mathrm{a}}$ & 9.35 & 3.1196 & 0.0058 \\
\hline
\end{tabular}

Dry matter ${ }^{1}$, organic matter ${ }^{2}$, crude protein ${ }^{3}$, ethereal extract ${ }^{4}$, neutral detergent fiber ${ }^{5}$, acid detergent fiber ${ }^{6}$, non-fibrous carbohydrates ${ }^{7}$, Coefficient of variation ${ }^{8}$ and standard error of the average 9 .

*Means followed by different letters in the same row differ statistically from each other using Tukey's test.

Even in animals that consumed less concentrate in their diets with the coconut meal, the lack of effect on the apparent digestibility of DM, $\mathrm{OM}, \mathrm{CP}, \mathrm{EE}$, and ADF can be explained by the compensatory effect described by Van Soest (1994). They found that when consumption decreases, the feed stays for a longer time inside the rumen, thus undergoing better degradation. Macedo Júnior et al. (2010) explained that in these situations, there is greater use of feed by ruminal microorganisms, thus obtaining better digestibility coefficients of the nutrients.

Souza Júnior et al. (2011) observed an increase in DM digestibility when they used coconut 
meal to replace roughage (Brachiaria humidicola) at three levels of inclusion (control: $0.4,0.8$, and $1.2 \%$ of CP), with higher DM digestibility value $(57 \%)$ at the highest level of inclusion of coconut meal. However, this value is lower than that observed in the present study, when compared with the inclusion of coconut meal at the level of $22 \%(66.48 \%)$. It should be noted that, in the present study, coconut meal replaced both corn and soybean meal, which are traditional used due to their high acceptability and digestibility.

The apparent digestibility results corroborate those observed by Pimentel et al. (2011), who evaluated cashew nut bran in diets for sheep, and found that in diets with increasing levels of EE, there is generally no effect or improvement in digestibility of CP. However, the lack of effect between the treatment with $11 \%$ coconut meal inclusion compared to the control suggests that the digestibility of the protein in the coconut meal is similar to that of soybean meal and corn. Pereira et al. (2010) observed that coconut meal has a highly digestible bypass protein in the intestine, with approximately $60 \%$ digestibility for the non-degradable protein in the rumen.

The digestibility of neutral detergent fiber corrected for ash and protein $\left(\mathrm{NDF}_{\mathrm{ap}}\right)$ was significantly lower in diets with the inclusion of coconut meal, with values of $65.85,56.16$, and $55.86 \%$ to zero; $11 \%$ and $22 \%$ inclusion of coconut meal, respectively. The diets that contained coconut meal in the composition provided a higher concentration of $\mathrm{NDF}_{\mathrm{ap}}$ resulting from the forage because the animals preferred the roughage feed over the concentrate. Thus, the higher proportional consumption of fiber from forage, with higher lignin content, was one of the main causes of the variation in NDF digestibility.

In addition, the high proportion of lipids in the diets with coconut meal may also have contributed to the reduced digestibility of the fiber, due to the covering of the particles by oil. This reduces the contact surface, preventing the degradation of the fibers by the microorganisms, and thereby reduces fiber digestion and feed intake (WANAPAT et al., 2011). In addition, the meal contains a high proportion of medium-chain saturated fatty acids that are toxic to microorganisms.

Similar data were obtained by Braga et al. (2009), who observed a reduction in NDF digestibility, from $72.50 \%$ to $64.43 \%$, when working with eight sheep divided into three levels of inclusion (control, $6 \%, 12 \%$, and $18 \%$ ) of coconut meal in the diet with Tifton 85 hay-based roughage. Irino et al. (2011), when evaluating the inclusion of coconut meal in the concentrated fraction of the diet with a roughage-concentrate ratio of 40:60, observed similar results. They found no effect on the BP digestibility and linear reduction of NDF digestibility, with values of $64.2 \%, 58.2 \%, 59.5 \%$, and $57.1 \%$ for the levels of $0 \%, 25 \%, 50 \%$, and $75 \%$ inclusion, respectively.

The digestibility of NFC was higher in diets containing coconut meal. However, there was no difference $(P<0.05)$ between the $11 \%$ and control diets. Although the inclusion of coconut meal reduced NFC levels and increased the levels of NDF, $\mathrm{ADF}$, and $\mathrm{EE}$ in the diets, there was an improvement in the digestibility of NFC. The probable explanation for this increase is associated with the longer time for which the feed remains in the animal gastrointestinal tract. The animals showed a predilection for the roughage fraction when fed diets with inclusions of coconut meal, but also in relation to the type of NFC ingested, sugars from the grass in relation to corn starch.

As shown in Table 6, according to the intake of $\mathrm{CP}$, the intake of $\mathrm{N}$ decreased $(P<0.0001)$ with the inclusion of $22 \%$ coconut meal in the diet, with values of $28.56 \%, 25.22 \%$, and $17.10 \%$ for the control, $11 \%$, and $22 \%$ treatments, respectively. However, the excretion of $\mathrm{N}$ through the feces was similar between treatments, resulting in a lower amount of $\mathrm{N}$ absorbed from the $22 \%$ diet.

Table 6. Nitrogen balance (NB) in sheep fed diets containing different concentrations of coconut meal.

\begin{tabular}{ccccccc}
\hline \multirow{2}{*}{$\begin{array}{c}\text { Item } \\
\text { (g/animal/day) }\end{array}$} & \multicolumn{2}{c}{ Concentration of coconut meal } & & \multirow{2}{*}{ VC $^{1}$} & $\mathrm{SE}^{2}$ & P value \\
\cline { 2 - 4 } & $0 \%$ & $11 \%$ & $22 \%$ & & & \\
\hline $\mathrm{N}$ ingested & $28.56^{\mathrm{a}}$ & $25.22^{\mathrm{a}}$ & $17.10^{\mathrm{b}}$ & 11.48 & 0.8374 & $<0.0001$ \\
$\mathrm{~N}$ fecal & 5.90 & 5.39 & 5.09 & 58.66 & 1.1427 & 0.8786 \\
$\mathrm{~N}$ urinary & $5.14^{\mathrm{a}}$ & $3.16^{\mathrm{b}}$ & $1.98^{\mathrm{c}}$ & 29.24 & 0.3544 & 0.0002 \\
$\mathrm{~N}$ absorbed & $22.67^{\mathrm{a}}$ & $19.83^{\mathrm{a}}$ & $12.01^{\mathrm{b}}$ & 22.01 & 1.3691 & $<0.0001$ \\
$\mathrm{~N}$ withheld & $17.52^{\mathrm{a}}$ & $16.31^{\mathrm{a}}$ & $9.63^{\mathrm{b}}$ & 27.42 & 1.5315 & 0.0044 \\
$\mathrm{~N}$ withheld (\%) & 61.11 & 65.69 & 58.66 & 27.94 & 6.5089 & 0.7111 \\
\hline
\end{tabular}

Coefficient of variation ${ }^{1}$ and standard error of the mean ${ }^{2}$

* Means followed by different letters on the same row differ statistically from each other using the Tukey test. 
Urinary $\mathrm{N}$ analysis showed that the animals that consumed less $\mathrm{N}$ tried to compensate for the lower $\mathrm{N}$ supply by excreting less $\mathrm{N}$ in their urine, even managing to retain the same proportion of $\mathrm{N}$ in relation to that consumed in the control treatment; however, they retained less $\mathrm{N}$ absolutely. The results obtained suggest that the $\mathrm{N}$ consumed was the main active parameter in the results of $\mathrm{N}$ balance, and not so much the quality of this $\mathrm{N}$, as, despite the supply of isoproteic diets, ad libitum consumption was taken into account, which would allow $10 \%$ leftovers. Similar to that in voluntary consumption, lower values were observed in the animal group that received a $22 \%$ inclusion of coconut meal, as a result of reduced intake of DM and protein.

However, despite the significant reduction in the percentage of $\mathrm{N}$ retained with $22 \%$ coconut meal, there was no negative balance in this group of animals who selected the larger fraction for consumption, indicating that the animals were able to select the digestible fractions of the diet and also show the quality of the forage offered.

\section{CONCLUSION}

Coconut meal can be used in the diets of finishing sheep, but attention should be paid to ensure that the EE intake does not exceed $0.16 \%$ of the BW and limit dietary intake. In the present study, the inclusion of $11 \%$ coconut meal in diets with a high concentrate portion $(70 \%)$ resulted in limited feed consumption. This necessitates further research to clarify the effective levels of coconut meal inclusion that do not affect animal consumption.

\section{ACKNOWLEDGMENT}

The authors thank the National Council for Scientific and Technological Development $(\mathrm{CNPq})$ and the Coordination for the Improvement of Higher Education Personnel (CAPES) via the National Academic Cooperation Program No. 071/2013 for their financial support. In addition, we also thank the members of the Study Group on Ruminants and Forage Production of Amazon (GERFAM) for their help in conducting the research.

\section{REFERENCES}

AOAC - Association of Official Analytical Chemists. Official methods of analysis. 15. ed. Washington: AOAC, 1990. 684 p.

BOSA, R. et al. Consumption and apparent digestibility of diets with different levels of inclusion of coconut pie for sheep feeding. Acta Scientiarum,

\section{4: 57-62, 2012.}

BRAGA, Z. C. A. C. et al. Evaluation of consumption and apparent digestibility of diets with different levels of coconut bran. Revista Caatinga, 22: 249-256, 2009

BRAINER, M. S. C. P. Coconut production: the Northeast is a national highlight. Sector notebook ETENE, s / v. 2018.

BRINGEL, L. M. L. et al. Consumption, digestibility and nitrogen balance in lambs fed palm oil pie to replace elephant grass silage. Revista Brasileira de Zootecnia, 40: 1975-1983, 2011.

CORREIA, I. M. S. et al. Evaluation of the potential and physicochemical characteristics of Sunflower (Helianthus annuus L.) and Coconut (Cocos nucifera L.) oil produced in Northeast Brazil. Scientia Plena, 10: 1-7, 2014.

DETMANN, E.; VALADARES FILHO, S. C. On the estimation of non-fibrous carbohydrates in feeds and diets. Brazilian Archive of Veterinary Medicine and Zootechnics, 62: 980-984. 2010.

FIORENTINI, G. et al. Digestibility, fermentation and rumen microbiota of crossbred heifers fed diets with different soybean oil availabilities in the rumen. Animal Feed Science and Technology, 181: 26-34, 2013.

FURNOLS, M. F.; GUERRERO, L. Consumer preference, behavior and perception about meat and meat products: An overview. Meat Science, 98: 361$371,2014$.

HERMUCHE, P. M. et al. Dynamics of Sheep Production in Brazil. ISPRS International Journal of Geo-Information, 2: 665-679, 2013.

HOE, T. K. The Current Scenario and Development of the Coconut Industry. The Planter, 94: 413-426, 2018

IRINO, M. M. X. et al. Apparent digestibility in sheep fed coconut bran in the Eastern Amazon. Revista de Ciências Agrárias, 54: 131-136, 2011.

LAMMERS, B. P.; BUCKMASTER, D. R.; HEINRINCHS, A. J. A simple method for the analysis of particle size of forage and total mixed rations. Journal of Dairy Science, 79: 922-928, 1996.

LIMA, N. L. L. et al. Economic analysis, performance, and feed efficiency in feedlot lambs. Revista Brasileira de Zootecnia, 46: 821-829, 2017. 
MACEDO JÚNIOR, G. L. et al. Consumption and apparent digestibility of fibrous fractions by pregnant ewes submitted or not to nutritional restriction. Brazilian Journal of Health Animal Production, 11: 179-192, 2010.

MARTINS, A. P. et al. The Problem of Coconut Post -consumption in Brazil: Alternatives and Sustainability. Debate Sustainability, 7: 44-57, 2016.

MEADE, B. et al. Corn and Soybean Production Costs and Export Competitiveness in Argentina, Brazil, and the United States. EIB-154, U.S. Department of Agriculture, Economic Research Service, 2016.

NRC - National Research Council. Nutrient Requirements of Small Ruminants. National Academic Press. 6. ed. Washington DC: The National Academies Press, 2007, 384 p.

OLIVEIRA, B. C. et al. Regulatory mechanisms of consumption in beef cattle: Physical factors, chemical factors, psychogenic factors, water intake. Nutritime Electronic Journal, 14: 6066-6075. 2017.

PALMQUIST, D. L.; MATTOS, W. R. S. Metabolismo de lipídeos. In: BERCHIELLI, T. T.; PIRES, A. V.; OLIVEIRA, S. G. (Eds.) Nutrição de Ruminantes. Jaboticabal, SP: Funep, 2011. cap. 10, p. 299-321.

PEREIRA, E. S. et al. Intestinal digestion of forage protein and agroindustry by-products produced in Northeast Brazil using the three-stage technique. Brazilian Journal of Health and Animal Production, 11: 403-413, 2010.

PIMENTEL, P. G. et al. Intake, apparent nutrient digestibility and ingestive behavior of sheep fed cashew nut meal. Revista Brasileira de Zootecnia, 40: 1128-1133, 2011

PINTO, A. C. J.; MILLEN, D. D. Nutritional recommendations and management practices adopted by feedlot cattle nutritionists: the 2016 brazilian survey. Journal of Animal Science, 99: 392-407, 2018.

RANIERI, C.; NUNES, B. C.; GAMEIRO A, H. Technological characterization of sheep production systems in Brazil. Animal Science Journal, 86: 476 $-85,2015$.

ROGÉRIO, M. C. P. et al. Feed management of goats and sheep in the tropics. Revista Veterinária e Zootecnia, 23: 326-346, 2016.
SANTOS, V. C. et al. Performance and digestibility of nutritive components of diets containing byproducts of oilseeds in lamb feed. Agricultural Sciences, 35: 1577-1586, 2014.

SOUZA JUNIOR, L. et al. Food intake and apparent digestibility of fibrous fractions of coconut pie for sheep. Acta Scientiarum. Animal Science, 33: 169$174,2011$.

SAS - Statistical Analysis Sistem. SAS/STAT: User's Guide (release 9.2). Cary: SAS Institute Inc, 2008

VAN SOEST, P. J. Nutritional ecology of the ruminant. 2. ed. Ithaca: Cornel University Press, 476 p., 1994.

WANAPAT, M. et al. Effects of vegetable oil supplementation on feed intake, rumen fermentation, growth performance, and carcass characteristic of growing swamp buffaloes. Livestock Production Science, 135: 32-37, 2011 